\title{
Powdery scab effect on the potato Solanum tuberosum ssp. andigena growth and yield
}

\author{
Elizabeth Gilchrist ${ }^{1}$, Juliana Soler ${ }^{1}$, Ueli Merz ${ }^{2} \&$ Sebastian Reynaldi $^{1}$ \\ ${ }^{1}$ Universidad Nacional de Colombia, sede Medellín. Calle 59A No.63-20. Medellín, Colombia; ${ }^{2}$ Plant Pathology, IBZ. \\ ETH Zurich, Universitätstrasse 2/LFW, 8092 Zurich, Switzerland
}

Author for correspondence: Elizabeth Gilchrist, e-mail: elygilchristr@hotmail.com

\begin{abstract}
Powdery scab affects most potato production zones in the world. The causal organism Spongospora subterranea f. sp. subterranea forms galls in roots and lesions on tubers during its replication. Recent researches suggest that $S$. subterranea could cause harmful effects on the host plant and potentially on yield. In order to quantify the disease impact on plant growth and yield, potato Solanum tuberosum ssp. andigena, cv. Diacol Capiro was grown in a soil infested with S. subterranea and compared to a healthy control soil. Data was taken at the flowering stage and at harvest. S. subterranea caused a plant length reduction of $23 \%$, a foliar dry weight reduction of $32 \%$ and a tuber weight reduction of $30 \%$, whereas $S$. subterranea did not reduce the number of tubers or stems.
\end{abstract}

Key words: Spongospora subterranea, Andisol, plant weight, tuber weight reduction.

\section{RESUMO}

Efeito da sarna pulverulenta no desenvolvimento e produtividade da batata Solanum tuberosum ssp. andigena

A sarna pulverulenta afeta a maioria das zonas de produção de batata no mundo. O organismo causador da doença, Spongospora subterranea f. sp. subterranea, forma galhas nas raízes e lesões em tubérculos durante a sua formação. Pesquisas recentes sugerem que $S$. subterranea pode causar efeitos deletérios sobre a planta hospedeira e, potencialmente, sobre o rendimento. Para quantificar o impacto da doença sobre o crescimento das plantas e o rendimento de batata, Solanum tuberosum ssp. andigena cv. Diacol Capiro foi cultivada em um solo infestado com S. Subterranea, comparando-se com solo de controle não infestado. Os dados foram tomados na fase de florescimento e na colheita. S. subterranea causou redução do comprimento de hastes da planta de $23 \%$, de peso da matéria seca foliar de $32 \%$ e de peso de tubérculos de 30\%. Contudo, não houve redução do número de tubérculos ou hastes.

Palavras-chave: Spongospora subterranea, Andissol, peso de plantas, redução do peso de tubérculos.

\section{INTRODUCTION}

Powdery scab affects main potato production zones in the world (Harrison et al., 1997; Merz, 2008; Merz \& Falloon, 2009) and is caused by Spongospora subterranea Wallr. Lagerheim f. sp. subterranea (S. subterranea), obligate parasite that can complete its life cycle in the Solanaceae plant family such as the potato ( $\mathrm{Qu} \&$ Christ, 2006). In potato, the parasite replicates in roots and stolons and on tubers (Merz \& Falloon, 2009), producing canker-like lesions in roots and stolons, called galls, and pustules on tubers (Harrison et al., 1997; Qu \& Christ, 2007). These structures contain resting spore aggregations (sporosori), which are highly stress-resistant and can remain dormant in the soil for more than 10 years (Merz et al., 2005). With the lack of efficient control strategies (Harrison et al., 1997; García et al., 2002; Falloon, 2008), powdery scab is a rising issue for both national and international trade, and affects a staple crop with great socioeconomic value and with a profound cultural attachment.
The international trade of infected seed disseminated the disease among the main potato producer regions in the world (Merz, 2008; Merz \& Falloon, 2009). Potato producers can suffer serious losses due to powdery scab. Diseased tuber lots may be completely rejected because of low tolerance limits for seed or may not fulfill the market standards when they are produced for mass consumption (Merz \& Falloon, 2009). S. subterranea has the potential to cause harmful effects on the host plant and hence to the crop yield (Lister et al., 2004; Falloon et al., 2005). So far, bioassay and field trials mainly looked for the relationship between genotype and powdery scab disease or agricultural measurements and yield (Taylor et al., 1986; Christ, 1989; Tuncer, 2002; Falloon et al., 2003; Merz et al., 2004; Genet et al., 2007; Iftikhar et al., 2007; Jaramillo \& Botero, 2007; Baldwin et al., 2008; Nitzan \& Brown, 2008; Nitzan et al., 2008, 2010; Houser \& Davidson, 2010). Therefore, the aim of this work was to study root disease development caused by $S$. subterranea and to determine the relationship to growth and yield of Solanum tuberosum L. ssp. andigena cv. Diacol Capiro in plots with infested and healthy soil. 


\section{MATERIALS AND METHODS}

\section{Experimental set up and growth conditions}

The trials were performed in the first semester of 2008 at the experimental station of the National University of Colombia, which is located at $2.561 \mathrm{~m}$ above sea-level, at $6^{\circ} 12^{\prime} 29.28^{\prime \prime} \mathrm{N}-78^{\circ} 29^{\prime} 5.34^{\prime \prime} \mathrm{O}$. The region has an annual average precipitation of $2.500 \mathrm{~mm}$ and temperature of $14^{\circ} \mathrm{C}$.

Experimental units (plots) used were containers made of concrete which were buried to soil level ( $\mathrm{w} \times 1 \times \mathrm{h}=100$ $\mathrm{cm} \times 100 \mathrm{~cm} \times 40 \mathrm{~cm})$. The containers were filled with noninfested soil (control) and soil infested with S. subterranea. The soil used was classified as Andisol (Jaramillo et al., 1994). Fifteen replicates/treatment were planted with four pre-sprouted tubers/plots.

At planting a nutritional complement was applied consisting of organic matter (chicken manure-100 g/plot), $\mathrm{MgSO}_{4}(5 \mathrm{~g} / \mathrm{plot})$ and nitrogen, phosphate and potassium $(1: 2: 2$ - $32 \mathrm{~g} / \mathrm{plot})$. When plants were $30 \mathrm{~cm}$ high, six weeks after planting (principal stadium 3, longitudinal growth) (Meier, 2001), another $48 \mathrm{~g}$ of nitrogen, phosphate and potassium (1:2:2) were applied per container. The plots were regularly weeded and treated with Fosetil-Al, Metalaxyl and Mancozeb and Lambdacihalotrina to control other diseases and pests, respectively. To assure a constant level of soil humidity, the plots were irrigated at a rate of 5 $\mathrm{cm}^{3} / \mathrm{min}, 4 \mathrm{~h}$ per day.

\section{Soil test}

To ensure the homogeneity of the inoculum concentration in the infested soils, three soil samples were taken from each of six random plots. The concentration of sporosori was determined following the procedures described by Beltrán et al. (2009).

\section{Plant growth and root disease severity and incidence}

For the production of a growth curve, plant length was measured weekly between leaf emergence and flowering, from plant neck to the highest leaf apex $(\mathrm{cm})$.

During the flowering stage, ten weeks after planting (principal stadium 6) (Meier, 2001), all plants of 5 randomly chosen plots per treatment were harvested, the number of stems per plant assessed and tuber fresh weight (g/plant) measured. The foliar and the root dry weight $(\mathrm{g} /$ plant) were determined after drying the plants for 30 days at room temperature and then for 48 hours at $70^{\circ} \mathrm{C}$ in a stove. The percentage of root surface covered by galls (severity) and the number of plants showing galls (incidence) were visually assessed (Harrison et al., 1997; Qu \& Christ, 2007). The presence of $S$. subterranea in the roots of each replicate was confirmed by molecular detection, using SsF and SsR primers, which generate a 434 bp product $(\mathrm{Qu}$ et al., 2006). DNA extractions were made after maceration and homogenization of roots from the same plot, taking a $100 \mathrm{mg}$ random sample of this macerate according to the protocol proposed by Qu et al. (2006) for potato peels with lesions.

\section{Yield and powdery scab severity and incidence}

At the time of senescence, 20 weeks after planting (principal stadium 97, leaves and stems dead) (Meier, 2001), all plots were harvested. Yield was determined as tuber fresh weight (g/plant). Average tuber weight (g) was calculated by dividing the total tuber weight of each plot by its number of tubers. Powdery scab incidence and severity of 10 randomly chosen tubers per plot were determined by counting the tubers with pustules and using the visual scoring scale by Falloon et al. (1995), respectively.

To determine effects caused by powdery scab, the percentage of differences in plant length and foliar dry weight, in yield and in tuber weight was calculated using the following equation, where $a$ is the average of the variables evaluated for infested soil and $b$ is the average of the variables evaluated for the control.

$$
\text { Reduction }(\%)=100-\frac{(100 * a)}{b}
$$

\section{Statistics}

A one-way ANOVA was performed to determine the differences between control and the infested soil $(p<95 \%)$. Data homoscedasticity and normality were analyzed using Levene and Kolmogorov-Smirnov tests, respectively. All the analyses were performed using the open source software R (CRAN 2009).

\section{RESULTS}

\section{Soil test}

In the infested plots, the average inoculum density was $1082 \pm 187$ sporosori per gram of soil and no significant differences were found $(p<0,05)$ among the plots and samples.

\section{Plant growth and root disease severity and incidence}

Average plant length at flowering (week 10) differed significantly $(p<0.05)$ between the control $(53 \mathrm{~cm})$ and the infested soil $(41 \mathrm{~cm})$ which represents a reduction of $23 \%$. This effect appeared first at hilling (Figure 1).

At flowering, all plants from the infested soil treatment showed galls which covered $4.6 \%$ of the root surface in average (Table 1). No root infection was found on the control plants which were confirmed by molecular detection.

Although the average tuber fresh weight at flowering was higher in the control (211.8 g/plant vs $183.6 \mathrm{~g} /$ plant in infested soil), the difference was not significant. Similarly, the difference found between the average number of stems per plant was also not significant (control: 4.5; infested: 5.5; Table 1). 


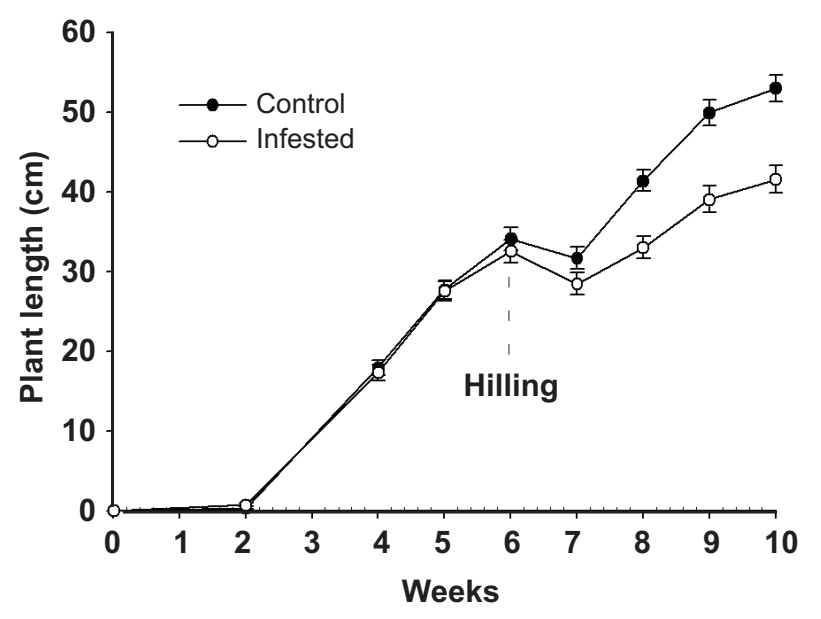

FIGURE 1 - Length of potato plants cv. Diacol Capiro grown until flowering in control (filled circles) and infested soil with Spongospora subterranea (empty circles). Average of 15 replications/treatment with four plants; bars represent $95 \%$ confidence intervals. The coefficient of variation for the control is 0.049 and for the infested soil is 0.035 .

TABLE 1 - PCR detection of Spongospora subterranea in roots, root gall incidence, severity and tuber fresh weight of potato plants cv. Diacol Capiro grown in infested and non-infested (control) soil

\begin{tabular}{|c|c|c|c|c|c|c|c|c|}
\hline \multirow[t]{2}{*}{ Sample } & \multirow[t]{2}{*}{$\mathbf{P C R}^{\mathrm{a}}$} & \multirow{2}{*}{$\begin{array}{c}\begin{array}{c}\text { Root gall } \\
\text { incidence }^{b}\end{array} \\
\%\end{array}$} & \multicolumn{2}{|c|}{ Root gall severity } & \multicolumn{2}{|c|}{ Tuber fresh weight } & \multicolumn{2}{|c|}{ Stem } \\
\hline & & & $\%$ & $\mathrm{CV}^{\mathrm{d}}$ & (g/plant) & $\mathrm{CV}$ & Number & $\mathrm{CV}$ \\
\hline Control & - & 0 & $0 \pm 00$ & 0 & $211.8 \pm 3$ & 0.075 & $4.5 \pm 0.72$ & 0.078 \\
\hline Infested & + & 100 & $4.6 \pm 0.7 * * *$ & 0.08 & $183.6 \pm 32$ & 0.086 & $5.5 \pm 0.72$ & 0.064 \\
\hline
\end{tabular}

${ }^{a}(+)$ and $(-)$ presence or absence, respectively, of the expected PCR product of 434 bp (Qu et al., 2006).

bPercentage of plants with galls; average of five replicatons with four plants.

'Percentage of root surface covered by galls; average of five replications with four plants; ${ }^{* * *}$ Significant difference $(p<0.001)$.

${ }^{\mathrm{d}}$ Coefficient of variation.

The foliar dry weight at flowering of the plants grown in infested soil was significantly reduced ( $19 \mathrm{~g} / \mathrm{plant})$ compared to the control (28 g/plant; Figure 2) but not the root dry weight $(6.3 \mathrm{~g} /$ plant in infested soil vs $5.8 \mathrm{~g} /$ plant $)$.

\section{Powdery scab severity, incidence and yield}

At harvest, average tuber surface covered by lesions was $1.08 \%$ in the control and $3.44 \%$ in the infested soil treatment and the percentage of diseased tubers was much higher in the infested soil (Table 2).

Tuber yield was significantly reduced from $771 \mathrm{~g}$ per plant in the control to $536 \mathrm{~g}$ per plant in the infested soil (Figure 3). The same effect was observed for the average tuber weight (Figure 4).

\section{DISCUSSION}

This work shows for the first time that root infection by $S$. subterranea of potato plants cropped under field conditions can reduce foliar mass and thus cause a drop in tuber yield. As little as $5 \%$ of root surface covered by galls can affect overall plant growth by decreasing plant height (23\%) and foliar dry weight (32\%), resulting in smaller tubers. Falloon et al. (2005) observed a substantial reduction of water uptake, plant dry matter and nutrient content when they compared inoculated potato plants with healthy ones. Plants were grown in pots filled with sand and were regularly supplied with nutrient solution. Six weeks after inoculation, the plant root systems were severely infected with $S$. subterranea, showing severe root galling. The authors assumed that the adverse effect might be due to reduced root uptake capacity due to reduced cell function, in particular of root hairs. Similar to their findings, we observed the first negative effect on plant growth 6 weeks after planting. Because the amount of nitrogen and carbon redistribution from foliage to tubers at the beginning of the senescence is directly related to leaf surface area, less carbon and nitrogen is available for tuber bulking (Kooman \& Rabbing, 1996). No significant difference was found in tuber number per plant between both treatments. This yield component is closely related to the number of stems per plant (Estrada, 1999) which was also similar.

In this work we found $32 \%$ of foliar dry weight reduction and $30 \%$ of potato tuber yield reduction and $5 \%$ of root gall formation. Similar results were reported by Gilchrist et al. (2009), who tested the same cultivar under the same soil conditions and showed a foliar weight reduction of $41 \%$, corresponding yield reduction of $40 \%$ and $1 \%$ of root gall formation. These results suggest 


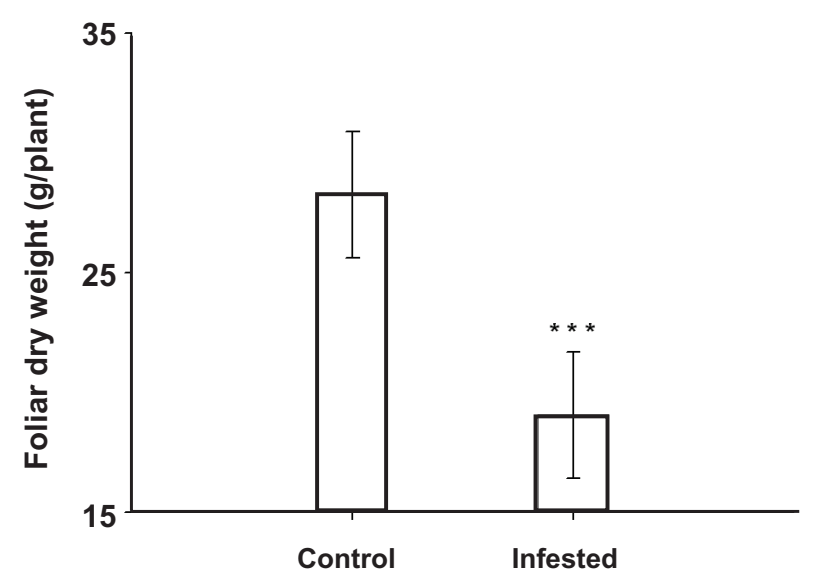

FIGURE 2 - Foliar dry weight at flowering of potato plants cv. Diacol Capiro grown in non-infested soil (control) and soil infested with Spongospora subterranea. Average of five replications with four plants; bars represent the $95 \%$ confidence intervals. $* * *$ Significant difference $(p<0.001)$. The coefficient of variation for the control is 0.046 and for the infested soil is 0.068 .

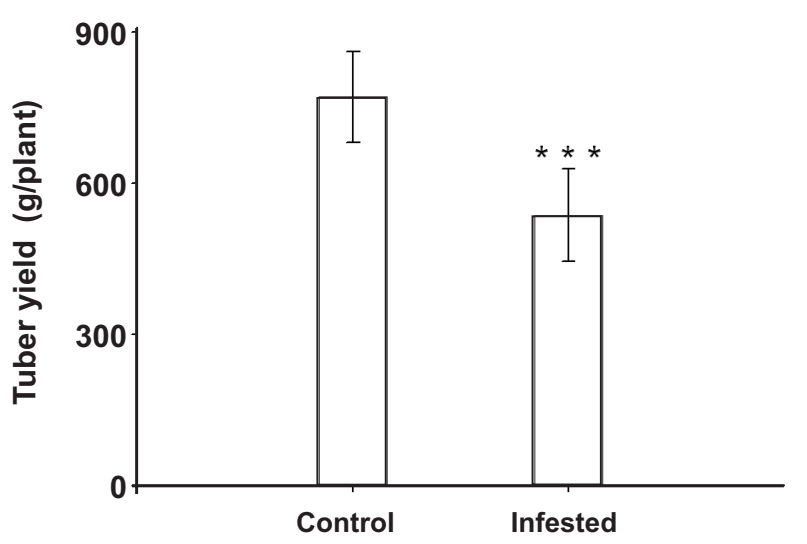

FIGURE 3 - Tuber yield (g/plant) at harvest of potato cv. Diacol Capiro grown in non-infested soil (control) and soil infested with Spongospora subterranea. Average of 10 replications with four plants; bars represent the $95 \%$ confidence intervals. $* * *$ Significant difference $(p<0.001)$. The coefficient of variation for the control is 0.056 and for the infested soil is 0.081 .

that the percentage of root gall formation does not have a linear relationship with foliar dry weight reduction or yield decrease.

Tubers of the non-infested treatment also showed some lesions but to a much lesser extent. It is possible that some plots were slightly contaminated by chance from the beginning or soil was transferred from the infested plots by wind or work.

Powdery scab has mainly been considered as a blemish disease, except for seed production and situations in which the cancer stage is occurring. It has now been confirmed that the reduced root capacity to uptake water and nutrient affects leaf assimilation which further reduces the average weight of the tubers but not their numbers per plant. This can become a problem in the potato production for the fresh market or processing where tuber size is crucial. Another issue raised by Falloon et al. (2005) is the disrupted water uptake as a potential threat for locations with limited water availability or increased demand due to global warming.

The cv. Diacol Capiro is a member of the andigena subspecies of Solanum tuberosum. Colombian potato producers crop exclusively cultivars of this subspecies together with Solanum phureja cultivars due to the proximity to the equator and the high altitude of the potato production areas. Another speciality of the Colombian potato production is the fact that there was never an international exchange of potato plant material so far. Consequently all the cultivars are national ones. Furthermore it has been observed that powdery scab disease occurs much more as root galling compared to tuber lesions and roots can sometimes be 'plastered' with gall-like structures (S. Jaramillo, 2010, Colombia, personal communication). It remains to be proven that tuberosum subspecies show a similar yield reduction effect caused by root infection. Some indication is given by Nitzan et al. (2008), who reported on observations of potato plants infected with the pathogen developed necrotic and deformed roots. The potato industry of Washington State, USA, is concerned with damage to roots caused by powdery scab and its potential to reduce yield weight in tonnage and affect tuber size and quality.

Haverkort et al. (1991) observed similar adverse effects on potatoes when infected by the cyst nematode

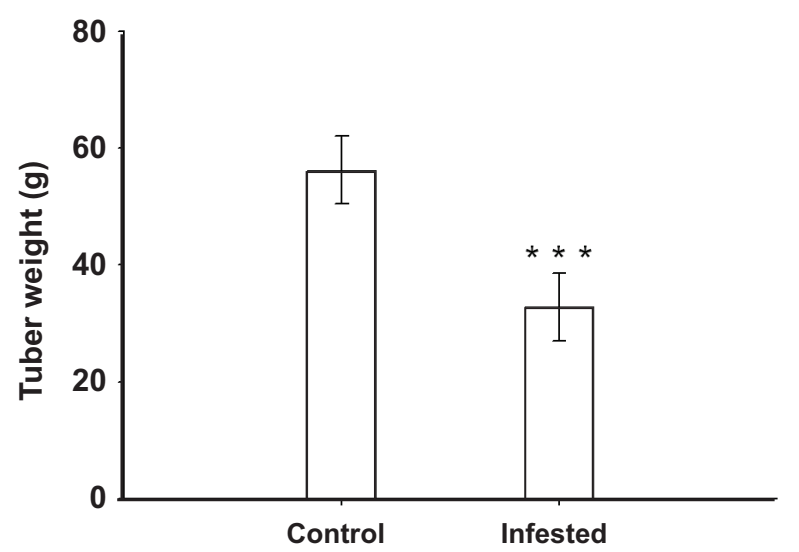

FIGURE 4 - Average tuber weight (g) at harvest of potato cv. Diacol Capiro grown in non-infested soil (control) and soil infested with Spongospora subterranea. Average of 10 replications with four plants; bars represent the $95 \%$ confidence intervals. $* * *$ Significant difference $(p<0.001)$. The coefficient of variation for the control is 0.047 and for the infested soil is 0.082 . 
TABLE 2 - Powdery scab severity and incidence and number of tubers at harvest of potato plants cv. Diacol Capiro grown in non-infested soil (control) and soil infested with Spongospora subterranea

\begin{tabular}{ccccccc}
\hline \hline Sample & Powdery scab severity on tubers & \multicolumn{2}{c}{$\begin{array}{c}\text { Powdery scab incidence on } \\
\text { tubers }\end{array}$} & \multicolumn{2}{c}{ Tuber per plant } \\
\hline & $(\%)$ & $\mathrm{CV}^{\mathrm{a}}$ & $(\%)$ & $\mathrm{CV}$ & Number & $\mathrm{CV}$ \\
\hline Control & $1.08 \pm 0.47$ & 0.226 & 20 & 0.153 & $14.1 \pm 1.8$ & 0.064 \\
Infested & $3.44 \pm 0.74 * *$ & 0.071 & 90 & 0.037 & $16.8 \pm 1.8$ & 0.053 \\
\hline
\end{tabular}

***Significant difference $(p<0.001)$.

${ }^{a}$ Coefficient of variation.

Globodera rostochiensis. Early nematode infection (until 43 days after planting) affected the plants in a comparable way as a simulated drought stress by reducing e.g. numbers of leaf, plant height and mean tuber weight. Like $S$. subterranea, nematodes also disrupt cortical cell function but their main damage is caused by draining the plant's photosynthate and nutrients.

\section{ACKNOWLEDGMENTS}

We thank Sonia Jaramillo and Juan Gonzalo Morales (Universidad Nacional de Colombia, sede Medellín) for helpful discussion. Funding for this project was provided by the Research Directorate (DIME) of the Universidad Nacional de Colombia and Colciencias (Contract 298 of 2008, Project number 15959).

\section{REFERENCES}

Baldwin SJ, Genet RA, Butler RC, Jacobs JME (2008) A greenhouse assay for powdery scab (Spongospora subterranea f. sp. subterranea) resistance in potato. Potato Research 51:163173 .

Beltrán E, Gilchrist E, Jaramillo S, Reynaldi S (2009) Influencia de las condiciones de incubación sobre la activación de zoosporas de Spongospora subterranea, en busca de un inóculo para el estudio de la sarna polvosa. Revista Facultad Nacional de Agronomía Medellín 62:5055-5062.

Christ BJ (1989) Effect of planting date and inoculum level on incidence and severity of powdery scab on potato. Potato Research 32:419-424.

Estrada N (1999) La biodiversidad en el mejoramiento genético de la papa. CIP - IPGRI - IBTA - PROINPA - COSUDE- CID. 371p.

Falloon RE, Viljanen-Rollinson SLH, Coles GD, Poff JD (1995) Disease severity keys for powdery and downy mildews on pea and powdery scab of potato. New Zealand Journal of Crop and Horticultural Science 23:31-37.

Falloon RE, Genet RA, Wallace AR, Butler RC (2003) Susceptibility of potato (Solanum tuberosum) cultivars to powdery scab (caused by Spongospora subterranea f. sp. subterranea), and relationship between tuber and root infection. Australasian Plant Pathology 32:377-385.

Falloon RE, Curtin D, Lister RA, Butler RC (2005) Root function and growth of potato plants reduced by Spongospora subterranea infection. American Journal of Potato Research 82:68.

Falloon RE (2008) Control of powdery scab of potato: Towards integrated disease management. American Journal of Potato Research 85:253-260.

García C, Pérez JC, Jaramillo S, Guerrero O, Benavides J, Ñustez C (2002) Evaluación del efecto de fungicidas aplicados al suelo para el manejo de $S$. subterranea. Subproyecto 3 de Evaluación de las estrategias de manejo de la roña polvosa (Spongospora subterranea) en las tres regiones más productoras de la papa en Colombia. pp. 23-27. http://www.redepapa.org/celsa.pdf. 60p.

Genet RA, Braam WF, Wallace AR, Falloon RE (2007) Susceptibility of potato cultivars and germplasm lines to powdery scab in New Zealand. www.spongospora.ethz.ch/EUworkshop07/ abstracts/Paper summary 2nd EPSW Cultivar powdery scab scores.pdf

Gilchrist E, Jaramillo S, Reynaldi S (2009) Efecto sobre la sarna polvosa de cuatro aislamientos del hongo Trichoderma asperellum en tres tipos de suelo. Revista Facultad Nacional de Agronomia Medellín 62:4783-4792.

Harrison JG, Searle RJ, Williams NA (1997) Powdery scab disease of potato - A review. Plant Pathology 46:1-25.

Haverkort AJ, Fasan T, Van De Waart M (1991) The influence of cyst nematodes and drought on potato growth. 2. Effects on plant water relations under semi-controlled conditions. Netherlands Journal of Plant Pathology 97:162-170.

Houser AJ, Davidson RD (2010) Development of a greenhouse assay to evaluate potato germplasm for susceptibility to powdery scab. American Journal of Potato Research 87:285-298.

Iftikhar S, Rattu A, Asad S, Burney K (2007) Susceptibility of potato cultivars to Spongospora subterranea under field conditions. Pakistan Journal of Botany 39:1329-1333.

Jaramillo DF, Parra LN, González H (1994) El recurso suelo en Colombia: Distribución y evaluación. Universidad Nacional de Colombia, ICNE. Medellín Colombia. 88 p.

Jaramillo S, Botero JM (2007) Respuesta de diferentes poblaciones de Spongospora subterranea f. sp. subterranea a la rotación entre dos variedades de papa (Solanum tuberosum spp. andigena). Revista Facultad Nacional de Agronomía Medellín 60:38593876.

Kooman PL, Rabbing R (1996) An analysis of the relation between dry matter allocation to the tuber and earliness of a potato crop. Annals of Botany 77:235-242.

Lister RA, Falloon RE, Curtin D, Butler RC (2004) Spongospora 
subterranea reduces host (Solanum tuberosum) growth. In: Ophel Keller KM, Hall BH (Eds.) Proceedings of the 3rd Australasian soilborne diseases symposium. South Australian Research and Development Institute. Adelaide Australia. pp.30-31.

Meier U (2001) Estadios de las plantas mono-y dicotiledóneas. BBCH Monografía. Centro Federal de Investigaciones Biológicas para Agricultura y Silvicultura. Cidade País 149 p.

Merz U, Martinez V, Schwärzel R (2004) The potential for the rapid screening of potato cultivars (Solanum tuberosum) for resistance to powdery scab (Spongospora subterranea) using a laboratory bioassay. European Journal of Plant Pathology 110:71-77.

Merz U, Walsh JA, Bouchek-Mechiche K, Oberhansli TH, Bitterlin W (2005) Improved immunological detection of Spongospora subterranea. European Journal of Plant Pathology 111:371-379.

Merz U (2008) Powdery scab of potato - occurrence, life cycle and epidemiology. American Journal of Potato Research 85:241-246.

Merz U, Falloon RE (2009) Powdery scab of potato - increased knowledge of pathogen biology and disease epidemiology for effective disease management. Potato Research 52:17-37.

Nitzan N, Brown C (2008) Effect of powdery scab on yield of Umatilla and Shepody potatoes. American Journal of Potato Research 85:22.

Nitzan N, Cummings TF, Johnson DA, Miller JS, Batchelor DL, Olsen C, Quick RA, Brown CR (2008) Resistance to root galling caused by the powdery scab pathogen Spongospora subterranea in potato. Plant Disease 92:1643-1649.
Nitzan N, Haynes KG, Miller JS, Johnson DA, Cummings TF, Batchelor DL, Olsen C, Brown CR (2010) Genetic stability in potato germplasm for resistance to root galling caused by the pathogen Spongospora subterranea. American Journal of Potato Research 87:497-501.

Qu XS, Christ BJ (2006) The host range of Spongospora subterranea f. sp subterranea in the United States. American Journal of Potato Research 83:343-347.

Qu XS, Kavanagh JA, Egan D, Christ BJ (2006) Detection and quantification of Spongospora subterranea f. sp. subterranea by PCR in host tissue and naturally infested soils. American Journal of Potato Research 83:21-30.

Qu X, Christ BJ (2007) In vitro culture of the obligate parasite Spongospora subterranea (Cercozoa; Plasmodiophorida) associated with root-inducing tranferred-DNA transformed potato hairy roots. Journal Eukaryotic Microbiology 54:465-467.

Taylor PA, Flett SP, de Boer RF, Marshall D (1986) Effects of irrigation regimes on powdery scab disease and yield of potatoes. Australian Journal of Experimental Agriculture 26:745-750.

Tuncer G (2002) The effect of irrigation and nitrogen on powdery scab and yield of potatoes. Potato Research 45:153-161.

\section{INTERNET RESOURCES}

CRAN (2009) The Comprehensive R Archive Network. http:// cran.r-project.org/. 